\title{
H/D Isotope Effects on Redox-switching of DNA Self-Assembled Monolayers observed by EQCM and Cyclic Voltammetry
}

Sarasi K.K. Galagedera, Gerd-Uwe Flechsig*

Department of Chemistry, University at Albany - SUNY, 1400 Washington Ave, Albany, NY 12222, United States

* Corresponding author: gflechsig@albany.edu

\section{Abstract}

An electrochemical quartz crystal microbalance (EQCM) was employed to study the interactions of hexammine ruthenium(III) (RuHex) and hexammine cobalt(III) (CoHex) with a mixed self-assembled monolayer of single-stranded DNA and 6-mercapto-1hexanol (ssDNA/MCH SAM) immobilized on gold electrodes. When the buffer medium was switched to deuterium oxide $\left(\mathrm{D}_{2} \mathrm{O}\right)$ from normal water $\left(\mathrm{H}_{2} \mathrm{O}\right)$, we observed a pronounced $H / D$ kinetic isotope effect where a consistent shift of up to $400 \mathrm{mV}$ was seen for the reduction peak potential of CoHex but not with RuHex. This was attributed to a 2400 -fold change of the apparent reaction rate constant. Though there was a dramatic increase in the EQCM frequency response at a millisecond time scale in the presence of both redox indicators, compared to the signal observed in a low ionic strength buffer (10 mM tris(hydroxymethyl)aminomethane (Tris)/ $\mathrm{H}_{2} \mathrm{SO}_{4}$ at $\mathrm{pH} 7.5)$, a $10 \mathrm{~Hz}$ decrease in the frequency shift was observed upon switching from $\mathrm{H}_{2} \mathrm{O}$ to $\mathrm{D}_{2} \mathrm{O}$-based buffer medium. The hydrogen bond network within the ssDNA layer seems to amplify the H/D isotope effect with CoHex. Amplified isotope effects may play a role in living systems. The mechanisms of recently reported H/D isotope effects in medicinal and biochemistry are still widely unclear. Voltammetric and EQCM studies of H/D isotope effects can provide a platform to investigate amplified isotope effects not only with DNA layers, but probably also with proteins and small organic molecules and may be useful for studies of cell proliferation, as well as drug testing.

\section{Introduction}

Isotope effects in electrochemistry have been occasionally studied since the first experiments of J. Heyrovsky with heavy water samples in the 1930s. He found that 
hydrogen evolution at mercury electrodes requires slightly more cathodic potentials when the electrolyte is based on heavy water [1]. The effect that Heyrovsky described was small $(-20 \mathrm{mV})$. Even more recent papers did not report isotope effects much greater than $-100 \mathrm{mV}{ }^{[2]}$. Electrochemical studies of isotope effects with systems other than hydrogen evolution are scarce. Erkang Wang et al. reported on an unusually large isotope effect with layers of vanadium hexacyanoferrate deposited on a Pt electrode of an EQCM: When in the aqueous electrolyte of $\mathrm{K}_{2} \mathrm{SO}_{4}$ the light water was replaced by heavy water, the redox signal of vanadium nearly disappeared, and hence, the voltammograms looked completely different in $\mathrm{H}_{2} \mathrm{O}$ and $\mathrm{D}_{2} \mathrm{O}{ }^{[3]}$. In contrast, a layer of nickel hexacyanoferrate did not show significant differences in voltammograms recorded in light and heavy water-based electrolytes ${ }^{[4]}$. Unfortunately, these interesting findings did not capture significant attention. More recently, relatively small $H / D$ kinetic isotope effects have been used to study the electrode reaction mechanisms of the reduction of oxygen ${ }^{[5,6]}$ and furfural ${ }^{[7]}$.

In medicinal chemistry and biochemistry, H/D isotope effects have been utilized to investigate reaction mechanisms of enzymes ${ }^{[8,9]}$. Incorporation of hydrogen isotopes into organic molecules is achieved by either direct hydrogen isotope exchange from the solvent or by a conventional synthesis involving multiple steps. If protons of interest are acidic and can be exchanged with water, usually the direct hydrogen exchange pathway is used. Such solvent isotope effects have been relatively small. Solvation in micelles based on SDS have been $20 \%$ slower in $\mathrm{D}_{2} \mathrm{O}$ compared to $\mathrm{H}_{2} \mathrm{O}$ [10]. The speed of kinesin-1 in gliding motility assays has been decelerated in $\mathrm{D}_{2} \mathrm{O}$ by $21 \%$, and in $\mathrm{H}_{2}{ }^{18} \mathrm{O}$ by $5 \%{ }^{[11]}$. Natural water comprises a low percentage of deuterium atoms $(0.01 \%)$ which are exchangeable between adjacent water molecules, thus carry a high interest in its biological effects on intracellular functions. Although deuterium oxide levels higher than $20 \%$ of body weight are lethal for higher life forms, low concentrations seem to be harmless for animals and humans ${ }^{[12]}$. Previous reports indicate this toxicity of deuterium oxide and the heavy damage it can cause to vital organs like mouse kidney ${ }^{[13]}$, yet there is a firm belief of its potential as an antiproliferative agent. In fact, the cell-free assay of GFP expression carried out by Hohlefelder et al. which have shown a considerable H/D isotope effect, give an indication of antiproliferative properties of heavy water ${ }^{[14]}$. Exceptions exist, and so, Vergara et al. could use water moss F. hygrometrica in high concentrations (90\%) of $\mathrm{D}_{2} \mathrm{O}$ to isolate deuterated chemicals ${ }^{[15]}$. Heavy water showed an inhibiting effect 
upon human pancreatic tumor cells in vitro ${ }^{[16]}$. A recent report by Strekalova et al. showed that deuterium-depleted water (DDW) has significant effects on depression in humans, as well as mice ${ }^{[17]}$. They found a correlation between geographical distribution of deuterium in tap water and depression. DDW also influenced the EEG parameters of sleep. These findings seem to confirm earlier reports of Somlyai et al. that DDW has an influence on various diseases ${ }^{[18,19]}$. According to them, changing the $H / D$ ratio in cells can influence certain molecular mechanisms that play a key role in cell cycle regulation. Thus, application of DDW may open new windows in cancer therapy ${ }^{[20]}$. Significant effects of DDW have also been observed in case of sunflower plants by Tanase et al. ${ }^{21]}$. In order to bring about any significant effects of deuterium depletion below the natural level of 155 ppm, certain amplification and deuterium accumulation processes or combinations thereof must probably exist in living organisms. Latest studies support the idea that an optimum level of deuterium can be found between 50 and 150 ppm [22].

Heavy water was also used to enhance super-resolution microscopy based on up to $54 \%$ increased photoemission of fluorescence labels ${ }^{[23]}$. Atzrodt et al. stated that the recent increased attention towards using hydrogen isotopes in pharmaceutical drug discovery is due to the enhanced sensitivity in detection and high reliability of the data obtained which outweigh the challenges in synthesizing the $(H, D$ or $T)$ labelled molecules and the cost associated ${ }^{[24]}$.

Electrochemical ${ }^{[25]}$, and gravimetric ${ }^{[26,27]}$ DNA biosensors have been frequently described. Also combined transductors are well-known ${ }^{[28]}$. Many electrochemical DNA sensors use covalently labeled probes ${ }^{[29]}$, targets, ${ }^{[30,31]}$ reporter or signaling strands ${ }^{[32]}$. DNA strands labelled with osmium tetroxide bipyridine have been used for hybridization detection on unheated and heated gold electrodes [33,34]. In controlling the analytical performance and reproducibility of DNA hybridization in any biosensor, the uniformity of the probe strand layer as well as its density is crucial ${ }^{[35,36]}$. It has been found that formation of modified surfaces with ds or ssDNA mixed with $\mathrm{MCH}$ can lead to heterogeneous surface packing densities giving rise to areas with lumps of DNA (aggregates) or multilayers ${ }^{[37]}$. Thus, the immobilization protocol plays a major role in producing a homogenous mixed monolayer with a fewer or no aggregates ${ }^{[38]}$. Twenty years ago, Steel et al. introduced their chronocoulometric method for the determination of DNA surface coverage based on RuHex. This complex is a redox marker that binds electrostatically in a defined stoichiometric ratio 
to the negatively charged nucleotide backbone/phosphate groups to quantify the surface density of ds or ssDNA immobilized on gold electrodes ${ }^{[39]}$. However, the strict 1:3 stoichiometry between RuHex and phosphate groups may not apply in all cases ${ }^{[40]}$. Electric and electrochemical potential pulses can improve the speed and stringency of DNA hybridization ${ }^{[41,42]}$. Moreover, the deposition of DNA SAMs can be accelerated by means of potential pulses ${ }^{[43]}$. Denaturation of immobilized dsDNA can be performed by means of very negative potentials without desorption of probe strands provided they are linked to multiplex-thiol groups leading to increased thermal and electrochemical stability ${ }^{[44,45]}$.

A very sensitive $35 \mathrm{MHz}$ QCM with dissipation (QCM-D) has been used by Tsortos et al. to investigate the energy dissipation due to deposition of viscoelastic layers such as DNA. The study of the acoustic ratio $\Delta \mathrm{D} / \Delta \mathrm{f}$ allowed to collect data about film density and thickness, as well as shear viscosity ${ }^{[45]}$. The authors described a linear relationship between the length of DNA oligos and the viscosity for strands shorter than 200 base pairs (bp). Viscosity also played a role with strands as short as 20 to $50 \mathrm{bp}$. Conformational changes of dsDNA that occurred upon binding of the Rad51 protein and polyamines have also been studied by QCM-D [46]. The electrochemical version of QCM-D (EQCM-D) has been utilized to influence the hybridization of DNA by means of applied potential pulses ${ }^{[28]}$. Although in that study, the applied potential pulses lead to the generation of a frequency response of a few $\mathrm{Hz}$ from the DNA layers, the authors focused more on how the pulses enhanced the hybridization efficiency rather than analyzing the cause of the frequency response.

Our main focus was the frequency response that is observed with such mixed SAMs of DNA/MCH and redox marker molecules. We have recently reported on redoxswitching of the viscoelasticity of DNA layers on gold observed with RuHex and CoHex in electrolytes made with light water ${ }^{[47]}$. In that earlier study we observed a difference in the frequency response of RuHex \& CoHex with ssDNA/MCH mixed SAMs which we think is related (as described in earlier reports) to CoHex that may form bridges between DNA strands coordinating not only with the phosphate backbone (as RuHex), but also with guanine bases ${ }^{[48]}$. In the current study we have investigated unusually large $H / D$ isotope effects on the interaction of our redox marker molecules and DNA layers observed in voltammetry, as well as significant isotope effects upon the redox-switching of viscoelasticity of the DNA layers as revealed by EQCM measurements. 


\section{Materials and Methods}

\subsection{Apparatus}

The voltammetric and EQCM measurements have been conducted by means of a PGSTAT 128N potentiostat/galvanostat (Metrohm-Autolab) equipped with an EQCM module with a measurable nominal frequency of $6 \mathrm{MHz}$. The EQCM cell contained a $\mathrm{Ag} / \mathrm{AgCl}$ reference electrode $(3 \mathrm{M} \mathrm{KCl})$ and a gold counter electrode. The diameter of the gold working electrode (on the surface of the $6 \mathrm{MHz}$ quartz crystal, diameter 1.36 $\mathrm{cm}$ ) in the EQCM cell was $0.67 \mathrm{~cm}$ with a thickness of $100 \mathrm{~nm}$. A Ti film with a thickness of $10 \mathrm{~nm}$ served as an adhesion layer between quartz surface and gold film. Gold disk electrodes (purchased from BASi, USA) used for voltammetric studies had a diameter of $1.6 \mathrm{~mm}$. A platinum wire counter electrode and $\mathrm{Ag} / \mathrm{AgCl}$ reference electrode in $3 \mathrm{M} \mathrm{KCl}$ was used along with the BASi gold disk electrode.

\subsection{Chemicals}

The 35-mer ssDNA thiolated probe (HLA DBP1) with the sequence of 5'GAT AGG ACC CAT ATT CCC ACT TTT TTT TTT TTT TT tris(dithioserinol) 3' was obtained from Biomers.net $\mathrm{GmbH}$ (Ulm, Germany). Deuterium oxide was obtained from ACROS Organics (Geel, Belgium). All the other reagents used for the experiments were purchased from Sigma-Aldrich (USA). They were of analytical grade and used without any further purification. All $\mathrm{H}_{2} \mathrm{O}$-based buffers were prepared using mega pure water. The immobilization buffer used was $10 \mathrm{mM}$ Tris containing $0.5 \mathrm{M}$ $\mathrm{Na}_{2} \mathrm{SO}_{4}$. The $\mathrm{pH}$ was adjusted to 7.5 using $\mathrm{H}_{2} \mathrm{SO}_{4}$ or $\mathrm{D}_{2} \mathrm{SO}_{4}$ as needed. The cyclic voltammetric, DPV, and EQCM experiments were performed in a measurement buffer consisting of $10 \mathrm{mM}$ Tris. The pH adjusted to 7.5 using either $\mathrm{H}_{2} \mathrm{SO}_{4}$ or $\mathrm{D}_{2} \mathrm{SO}_{4}$.

\subsection{Immobilization Procedure}

The gold disk electrode was cleaned by polishing with aluminum oxide powder $(0.3 \mu \mathrm{m} \& 0.05 \mu \mathrm{m})$ followed by electrochemical cleaning in $0.5 \mathrm{M} \mathrm{H}_{2} \mathrm{SO}_{4}$ using cyclic voltammetry $\left(0.1\right.$ to $1.7 \mathrm{~V}, 30$ cycles, scan rate $\left.200 \mathrm{mV} \mathrm{s}^{-1}\right)$. The gold electrode in the EQCM cell was subjected only to electrochemical cleaning ( 0 to $1.2 \mathrm{~V}, 10$ cycles, scan rate $25 \mathrm{mV} \mathrm{s}^{-1}$ ) before immobilization. The modified gold electrodes with highdensity ssDNA/MCH mixed SAMs were prepared using previously described protocol of Peter et al. ${ }^{[47]}$. 


\section{Results and Discussion}

\subsection{H/D Isotope Effect observed in Cyclic Voltammetry}

During our initial investigations to find the $E_{1 / 2}$ values of CoHex and RuHex in order to apply the optimal potential values for the potential jumps in EQCM experiments, cyclic voltammetry and differential pulse voltammetry were performed as depicted in Fig 1. The CV studies were performed after immobilizing a high-density ssDNA/MCH mixed SAM [(6.14 \pm 0.95$\left.) \mathrm{pmol} / \mathrm{cm}^{2}\right]$ on a gold electrode with $50 \mu \mathrm{M}$ CoHex or RuHex in $10 \mathrm{mM}$ Tris buffer made with $\mathrm{H}_{2} \mathrm{O}$ or $\mathrm{D}_{2} \mathrm{O}$. Here we observed a dramatic difference in the redox behavior of CoHex in $\mathrm{D}_{2} \mathrm{O}$ and $\mathrm{H}_{2} \mathrm{O}$ (Fig. $1 \mathrm{~B} \& \mathrm{D}$ ) whereas the behavior of RuHex (Fig. 1 A\&C) was very similar in both buffers.
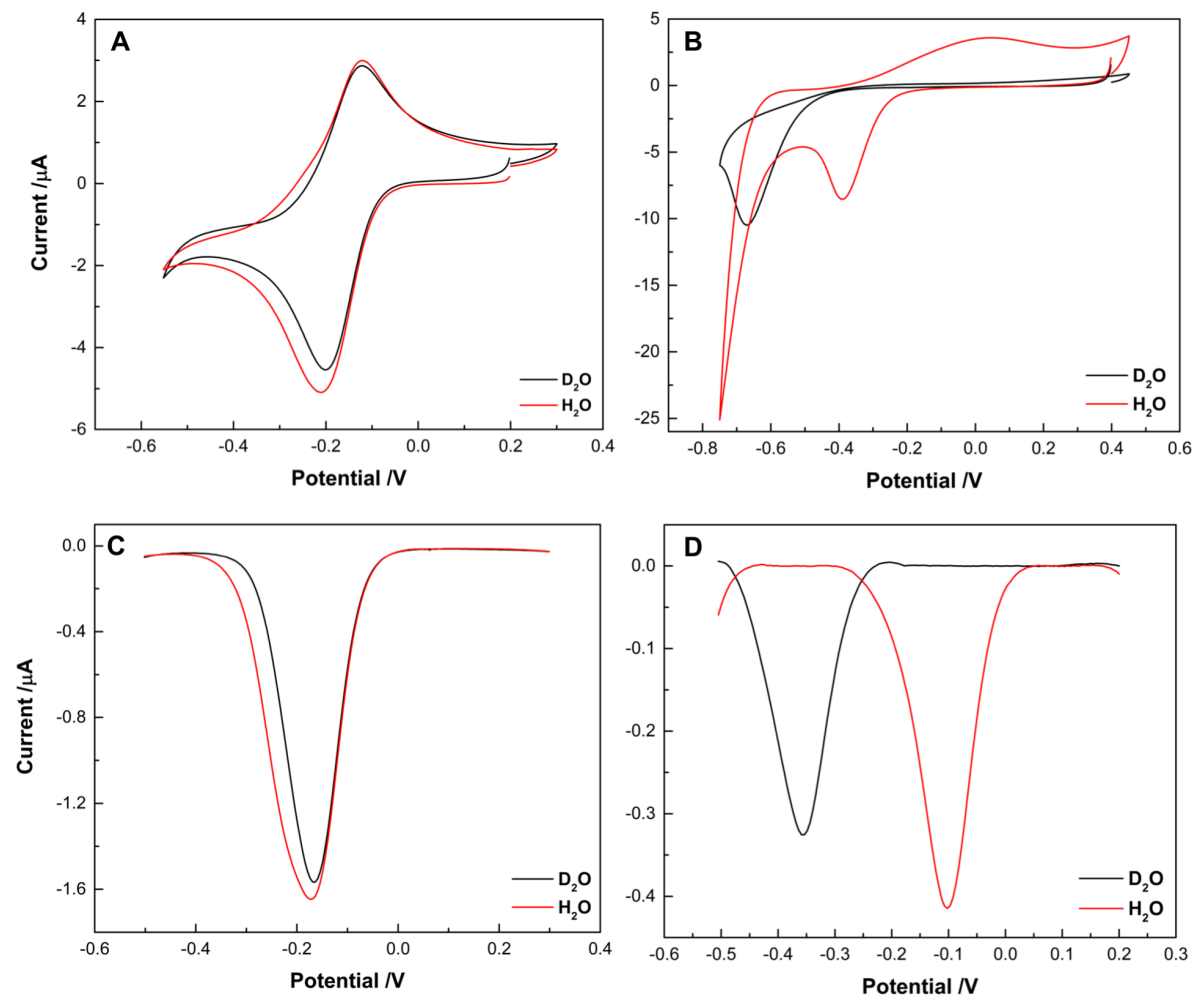

Figure 1. Kinetic isotope effect observed in A, B) cyclic voltammetry and C, D) differential pulse voltammetry with high density ssDNA/MCH modified gold electrodes in $10 \mathrm{mM} T \mathrm{Tris} / \mathrm{H}(\mathrm{D})_{2} \mathrm{SO}_{4}, \mathrm{pH} 7.5$ buffer containing $50 \mu \mathrm{M}$ of $\mathrm{A}, \mathrm{C}$ ) RuHex and $\mathrm{B}, \mathrm{D})$ CoHex. CV scan rate was $250 \mathrm{mV} \mathrm{s}^{-1}$.

For CoHex, the oxidation peak was almost gone in $\mathrm{D}_{2} \mathrm{O}$-based buffer and the peak separation was even greater than in the $\mathrm{H}_{2} \mathrm{O}$-based buffer. Interestingly, the reduction peak potential of $\mathrm{CoHex}$ in $\mathrm{D}_{2} \mathrm{O}$ was shifted towards a much more negative value than in $\mathrm{H}_{2} \mathrm{O}$. As shown in Fig. 3, a consistent shift of $\sim 400 \mathrm{mV}$ was detected in the reduction peak potential for $\mathrm{CoHex}$ in $\mathrm{D}_{2} \mathrm{O}$-based buffer when in contact with a 
ssDNA/MCH mixed SAM. A control experiment with a bare gold electrodes and $200 \mu \mathrm{M}$ CoHex in $\mathrm{H}_{2} \mathrm{O}$ and $\mathrm{D}_{2} \mathrm{O}$-based Tris buffers revealed no isotope effects on the peak potentials (Fig 2).
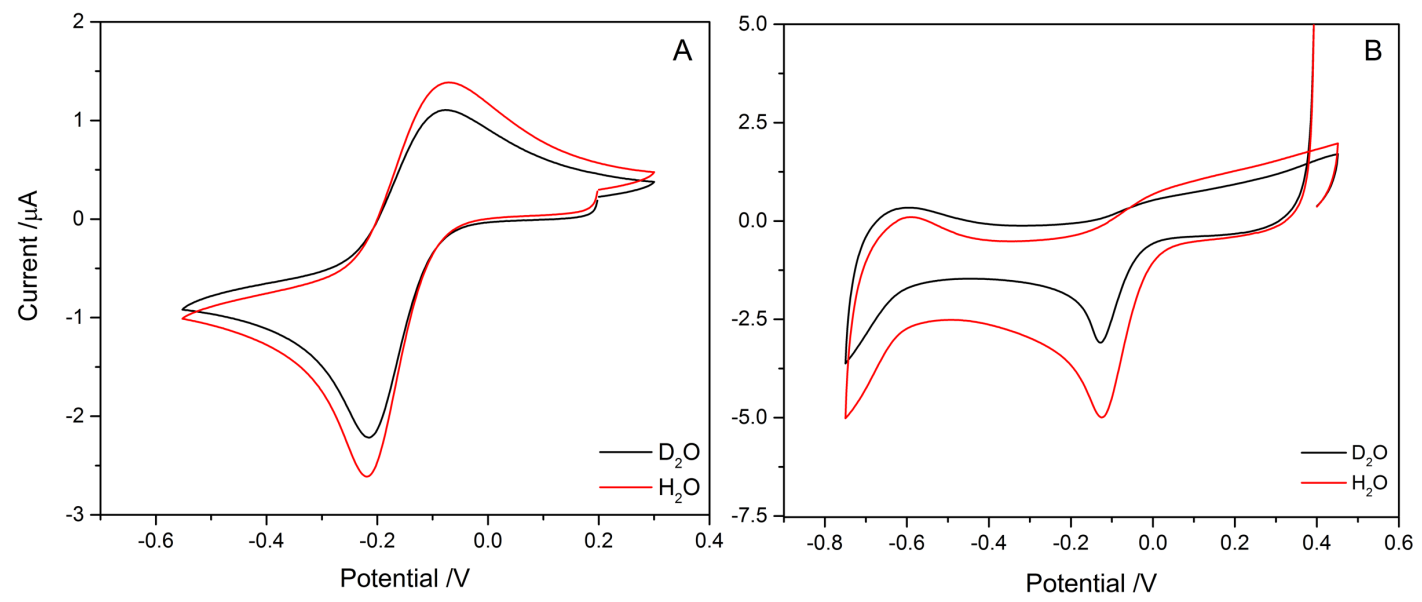

Figure 2. Cyclic Voltammetric behavior of $200 \mu \mathrm{M}$ A) RuHex and B) CoHex at a scan rate of $250 \mathrm{mV}$ $\mathrm{s}^{-1}$, in $10 \mathrm{mM} \mathrm{Tris} / \mathrm{H}(\mathrm{D})_{2} \mathrm{SO}_{4}$ made with $\mathrm{H}_{2} \mathrm{O}$ (Red) and $\mathrm{D}_{2} \mathrm{O}$ (Black) $\mathrm{pH} 7.5$ at bare BASi Au disk electrode.

Electrochemical reaction kinetics that applies to irreversible reactions in thin layers has been described by Hubbard in Equation 1 ,

$E_{P}=E^{0}-\left(\frac{2.3 R T}{\alpha n_{0} F}\right) \log \left[\frac{\alpha n_{0} F|v| V}{A R T k^{0}}\right]$

where $E_{P}$ is the peak potential, $E^{0}$ the standard electrode potential, $T$ the temperature, $\mathrm{R}$ the gas constant, $\alpha$ the transfer coefficient, $\mathrm{n}_{0}$ the number of electrons transferred, $\mathrm{F}$ the Faraday constant, $v$ the scan rate, A the electrode area, $V$ the volume of the thin layer, and $k^{0}$ the apparent electron transfer rate ${ }^{[49]}$.

Effects of both the scan rate $v$ and the apparent rate constant $k^{0}$ are visible in Fig. 3 as drifts with the scan rate and a constant offset, respectively, with the latter only visible in case of CoHex. This means the $\mathrm{k}^{0}$ is nearly the same for both $\mathrm{H}_{2} \mathrm{O}$ and $\mathrm{D}_{2} \mathrm{O}$ in case of RuHex. The $-400 \mathrm{mV}$ drift in cathodic peak potential means a factor $\mathrm{k}_{\mathrm{H}} / \mathrm{k}_{\mathrm{D}}$ of approx. 2400. In comparison, one of the largest kinetic isotope effects reported so far has been catalytic autooxidation of cumene $\left(\mathrm{k}_{\mathrm{H}} / \mathrm{k}_{\mathrm{D}}=76\right)^{[50]}$. The drift with scan rate in our voltammetric experiments was the same in all cases $(\Delta \mathrm{E} \sim-\log (|v|)$. We deduced that this isotope effect arises due to the difference in interaction with the 
sSDNA SAM and the redox complex as described earlier ${ }^{[47]}$, where ammonia ligands of CoHex form hydrogen bonds with guanine bases and in contrast, RuHex interacts with the negatively charged phosphate backbone only. RuHex has been described to cover the negatively charged DNA strand and provide some conductivity [51].

Therefore, the most relevant difference between CoHex and RuHex may be that in order to transfer electrons, the former has to enter the DNA layer, while the latter does not. This situation is illustrated in Scheme 1. While this mechanism may explain the basic difference between RuHex and CoHex in terms of EQCM behavior, it does not explain the stark solvent isotope effect of heavy water. Here, an additional effect may play a role: Similar to the entropy effect with chelate complexation, the multiple binding of CoHex to phosphates and bases by hydrogen bonds may lead to a similar entropic amplification of the isotope effect.
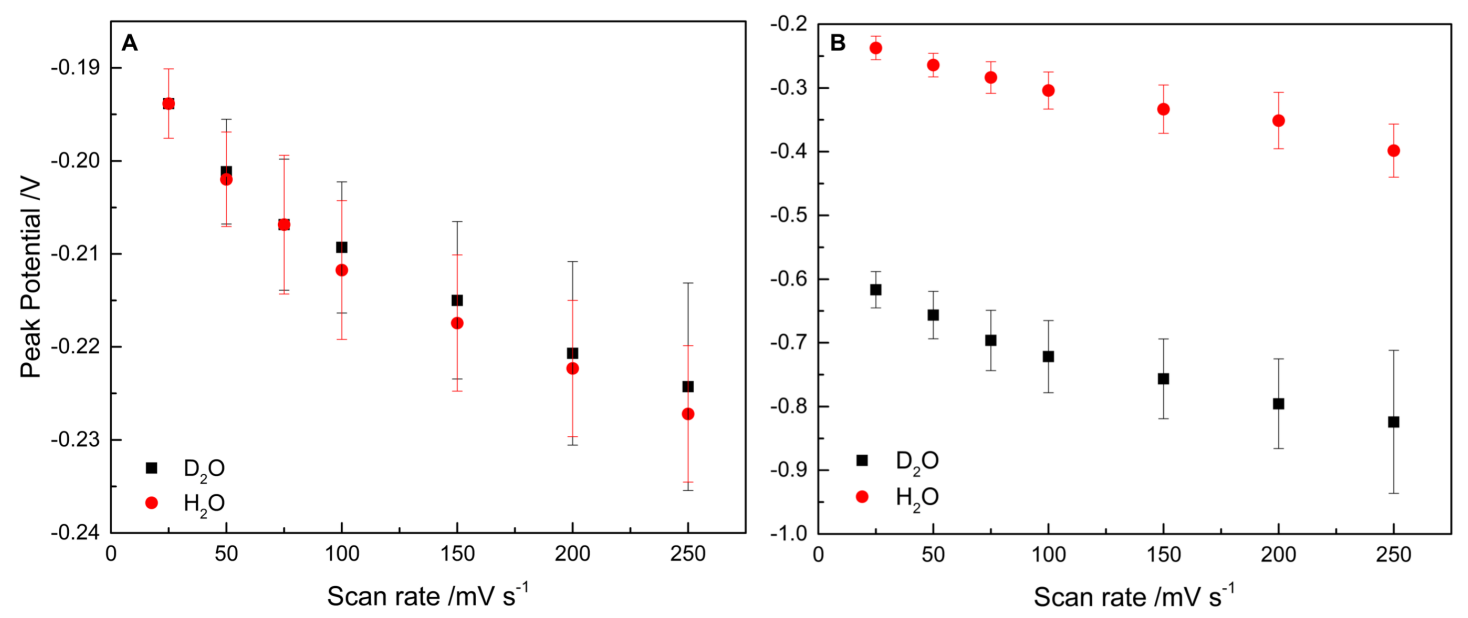

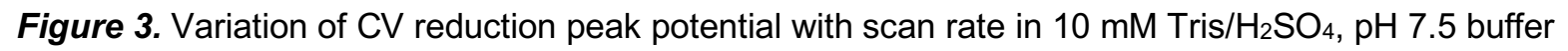
containing $50 \mu \mathrm{M}$ of $\mathrm{A}$ ) RuHex and $\mathrm{B}$ ) CoHex on high density ssDNA/MCH modified gold electrodes (EQCM Au electrode). The reduction peak potential values/data points represent the average value of 3 trials, each performed with a new SAM.

Table 1: Calculated half wave potentials (E1/2) of RuHex and CoHex at ssDNA-MCH modified Au electrode from cyclic voltammetry in $10 \mathrm{mM}$ Tris/H2SO4 with $\mathrm{H} 2 \mathrm{O}$ or $\mathrm{D} 2 \mathrm{O}, \mathrm{pH} 7.5$

\begin{tabular}{|c|c|c|}
\hline Complex & $\mathbf{E}_{1 / 2(\mathrm{D} 2 \mathrm{O})} / \mathbf{V}$ & $\mathbf{E}_{1 / 2(\mathrm{H} 2 \mathrm{O})} / \mathbf{V}$ \\
\hline RuHex & $-0.1690 \pm 0.0025$ & $-0.1741 \pm 0.0018$ \\
\hline CoHex & $-0.360 \pm 0.073$ & $-0.202 \pm 0.027$ \\
\hline
\end{tabular}



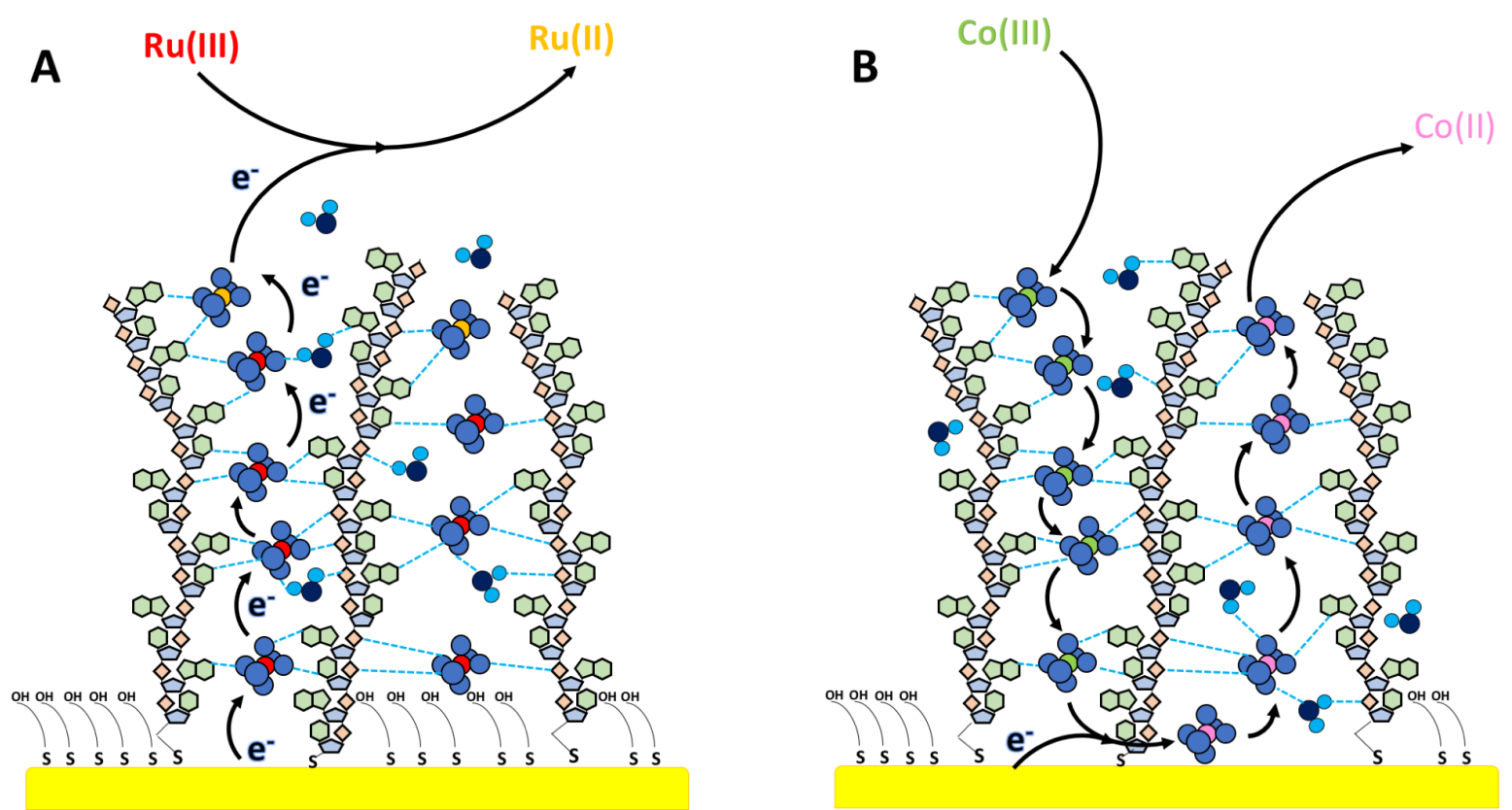

Scheme 1. Proposed schematic of the charge transfer mechanism in SSDNA SAMs conjugated with hexammine metal complexes each at a sufficiently reductive potential, by $A$ ) electron hopping enabled by RuHex and B) diffusion of redox-active CoHex through the SAM.

The shift of the equilibrium constant $\mathrm{K}$ can be calculated from the shift of standard potential based on the Nernst equation (Equation 2), where, $n$ is the number of electrons transferred during the reaction, $\mathrm{F}$ is the Faraday constant, $\mathrm{T}$ is the temperature (in $\mathrm{K}$ ) and $\mathrm{R}$ is the universal gas constant.

$E^{0}=\frac{R T}{n F} \ln K=\frac{0.0592 V}{n} \log K$

The observed -158 mV shift of the half-wave potential corresponds to a 467-fold shift of the regarding equilibrium. As reversibility was also changed, we performed differential pulse voltammetry (DPV) (Fig. 1 C, D). In DPV, we observed -250 mV potential shift in the case of CoHex, which would correspond to a 10,000-fold equilibrium shift; however, in case of irreversible electrode reactions, the half wave potential cannot be used to calculate thermodynamic parameters ${ }^{[52]}$. In comparison, a shift of the $\mathrm{pK} \mathrm{K}_{\mathrm{a}}$ of boric acid by 5 orders of magnitude was observed upon complexation with chelating poly-alcohols such as mannitol ${ }^{[53]}$, and the complexation of $\mathrm{Cu}(\mathrm{II})$ with triethylene tetramine (trien) instead of $\mathrm{NH}_{3}$ leads to a shift of formation constant $\left(\mathrm{pK}_{\mathrm{f}}\right)$ from -12.6 to $-20.5^{[54]}$. When RuHex is electrostatically bound to ssDNA on the electrode surface, it can increase the conductivity of such SAMs dramatically ${ }^{[40,55]}$. In comparison, with a $t^{5}{ }_{2 g} / t^{6}{ }_{2 g}$ low spin electron configuration in RuHex, to the $t^{6}{ }_{2 g} / t^{5}{ }_{2 g} \mathrm{e}^{2} \mathrm{~g}$ low spin/high spin switch configuration in CoHex ${ }^{[57]}$, the 
latter does not allow such accelerated electron transfer and conductivity effects in ssDNA SAMs. In fact, the rate constants for electron self-exchange reactions have been reported to be $9.6 \times 10^{2}$ and $2 \times 10^{-8} \mathrm{~L} / \mathrm{mol} \mathrm{s}$ for RuHex and CoHex, respectively ${ }^{[57]}$. The two proposed mechanisms of charge transfer are illustrated in Scheme 1.

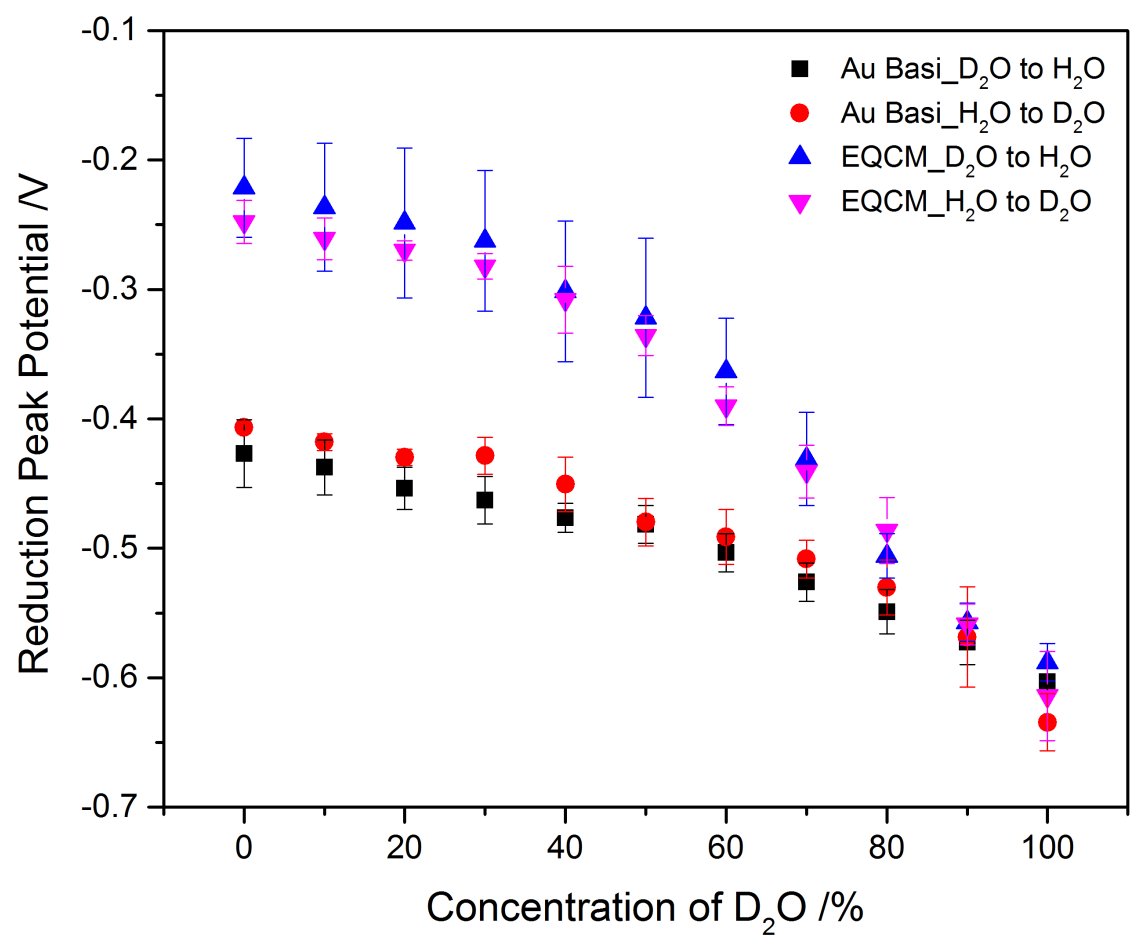

Figure 4. Variation of $\mathrm{D}_{2} \mathrm{O}$ content of the $10 \mathrm{mM}$ Tris/ $\mathrm{H}_{2} \mathrm{SO}_{4}$ buffer $(\mathrm{pH} 7.5)$ containing $50 \mu \mathrm{M}$ CoHex on the $\mathrm{Co}$ (III) reduction peak potential observed with high density ssDNA/MCH modified EQCM gold electrode (blue \& pink) \& BASi disk gold electrode (black \& red). CV was performed with a scan rate of $250 \mathrm{mV} \mathrm{s}^{-1}$. The reduction peak potential values (data points) are a representative of the average of 3 trials, each time using a new SAM immobilized on the Au electrode.

We performed control experiments with bare gold electrodes in both $\mathrm{H}_{2} \mathrm{O}$ and $\mathrm{D}_{2} \mathrm{O}$ based TRIS buffer electrolytes. These controls as depicted in Fig. 2 revealed that no isotope effect on peak potentials was visible without DNA-SAM and confirmed that only DNA-SAM as a diffusion barrier would induce the isotope effect.

\subsection{Effect of $\mathrm{D}_{2} \mathrm{O}$ Concentration in the Buffer}

After observing the difference in redox behavior of CoHex in both buffers, an extended study using cyclic voltammetry was carried out by changing the concentration of $\mathrm{D}_{2} \mathrm{O}$ in the measurement buffer to further explore the influence of $\mathrm{D}_{2} \mathrm{O}$ on the reduction peak potential of CoHex. We compared the results obtained 
using EQCM gold electrodes and Au BASi disk electrodes in Fig. 4. The results indicated a shift of $\sim 400 \mathrm{mV} \mathrm{s}^{-1}$ (Fig 4. Blue \& Pink) in the reduction peak potential of CoHex with the EQCM Au electrode when the concentration of the measurement buffer was changed from $0 \%$ to $100 \% \mathrm{D}_{2} \mathrm{O}$. This shift was consistent regardless of the order of the measurements performed (starting from $100 \% \mathrm{H}_{2} \mathrm{O}$ containing buffer to $100 \% \mathrm{D}_{2} \mathrm{O}$ containing buffer and vice versa). Whereas with the BASi Au electrode, the shift in the reduction peak potential was $\sim 250 \mathrm{mV} \mathrm{s}^{-1}$ (Fig 4. Red \& Black). The difference in the reduction peak shift values with both electrodes can probably be explained by the different surface structure of the electrodes containing the immobilized ssDNA/MCH mixed SAMs. Since the very flat surface of the EQCM Au electrode causes a better ordered DNA layer that allows more CoHex ions to chelate with guanine bases of the immobilized ssDNA and interact with $\mathrm{D}_{2} \mathrm{O} / \mathrm{H}_{2} \mathrm{O}$ molecules in the medium, leading to an enhanced isotope effect.

The most probable explanation for the observed shift in peak potentials seems to be the charge transfer mechanism illustrated in Scheme 1, where the exchange of metal complex ions and electron transfer in the ssDNA SAM is depicted: Electron transfer can proceed very quickly within RuHex-conjugated SSDNA-SAM unaffected by isotope effects, whereas with CoHex this is not possible. The electron self-exchange rate constant for CoHex is 48 billion times lower than that for RuHex [57]. In SsDNASAMs coordinated with CoHex, this complex ion has to move in and out in order to enable the electron transfer. Since CoHex interacts not only with phosphates, but also with guanine, it is relatively difficult to move. Replacing the solvent $\mathrm{H}_{2} \mathrm{O}$ by $\mathrm{D}_{2} \mathrm{O}$ leads to rapid exchange of all $\mathrm{O}-\mathrm{H}$ or $\mathrm{N}-\mathrm{H}$ acidic protons by deuterons making all hydrogen bonds stronger. In a chelate-like coordination, this will lead to the observed amplified isotope effect. This mechanism is also responsible for the missing oxidation peak of $\mathrm{CoHex}$ in $\mathrm{D}_{2} \mathrm{O}$. The reduction peak of $\mathrm{Co}(\mathrm{III})$ is greatly shifted to the negative; however, the mass transport of $\mathrm{Co}$ (III) from the bulk is only slowed down by the DNASAM. By the time, when the potential scan reaches the oxidative values for Co(II), there is not much $\mathrm{Co}(\mathrm{II})$ left in the vicinity of the electrode surface. Most has disappeared into the bulk, and only what was available in the SAM can be oxidized. The recently described water superstructures interacting with DNA ${ }^{[56]}$ may also contribute energetically and entropically to the observed isotope effects. 


\subsection{EQCM Frequency Response with RuHex \& CoHex in Heavy Water Buffer}

Next, the interactions of the different redox species with the ssDNA/MCH mixed SAMs were studied using the EQCM frequency response. Here, in comparison to our previous studies ${ }^{[47]}$ with light water-based measurement buffers, a notable decrease in the frequency shift values (by $\sim 10 \mathrm{~Hz}$ ) was observed in heavy water buffers for both RuHex and CoHex as shown in Fig 5 . One possible explanation for the decrease in the frequency response may be due to the difference in the interaction of the outer hydration shell of each of the redox species with $\mathrm{H}_{2} \mathrm{O}$ and $\mathrm{D}_{2} \mathrm{O}$ molecules in the buffer medium. Heavy water being $20 \%$ higher in viscosity than light water, may influence considerably the viscoelastic properties of the SAMs on the gold electrodes, which will cause indirect effects on the diffusion of species in and out of the monolayer. In addition, there might be a ligand exchange process going on between ammonia and $\mathrm{H}_{2} \mathrm{O} / \mathrm{D}_{2} \mathrm{O}$ with the chelated redox complexes on the ssDNA. Investigations are underway for the mechanism of this exchange.
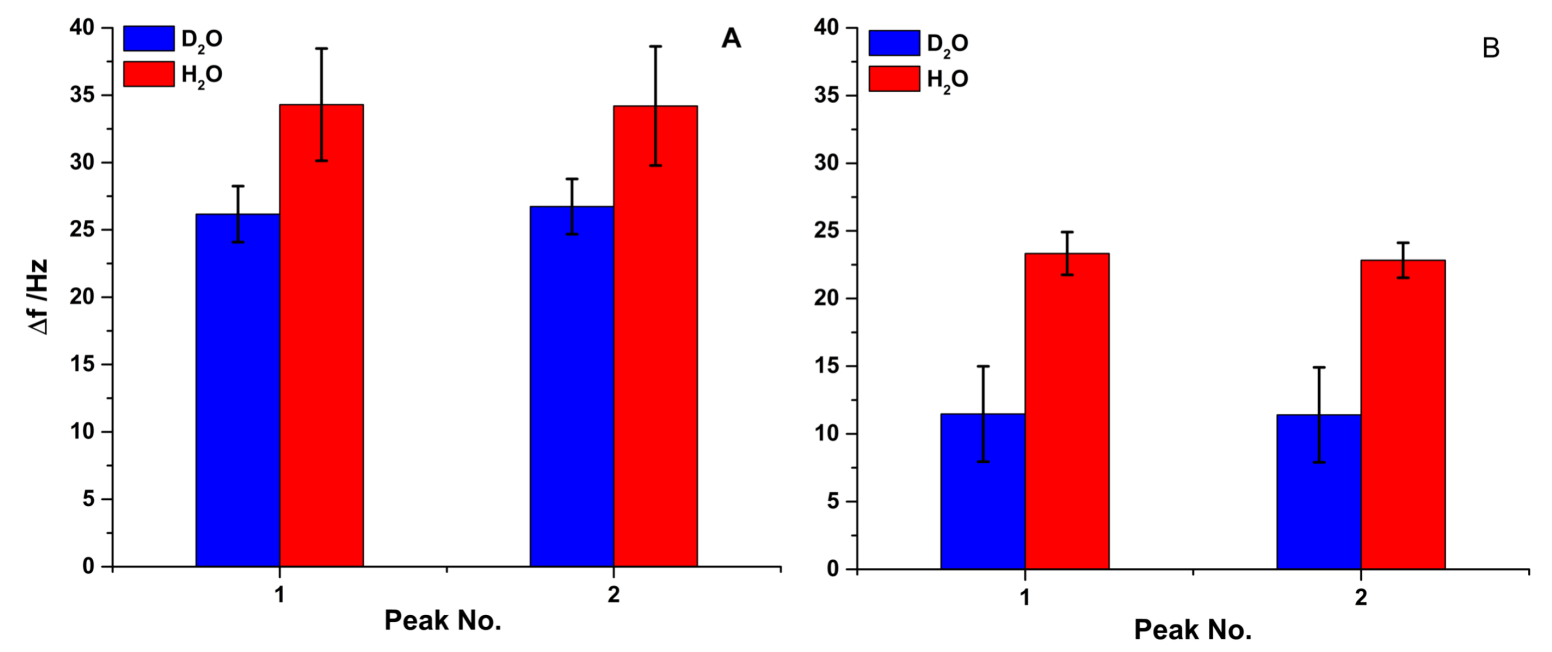

Figure 5. Frequency response of ssDNA/MCH mixed SAMs upon addition of $50 \mu \mathrm{M} \mathrm{A}$ ) RuHex B) CoHex to $10 \mathrm{mM}$ Tris/ $\mathrm{H}_{2} \mathrm{SO}_{4}$ buffer made with $\mathrm{H}_{2} \mathrm{O}$ (red) \& $\mathrm{D}_{2} \mathrm{O}$ (blue) $\mathrm{pH} 7.5$.

\subsection{Effect of the Concentrations of RuHex and CoHex}

We further investigated the effect of the metal complex concentrations on the redox switching EQCM response of the mixed ssDNA/MCH SAMs with $\mathrm{D}_{2} \mathrm{O}$ based measurement buffer (Fig 6 A\&B). According to the study, we observed that the detection limit for RuHex in Tris buffer made with $\mathrm{D}_{2} \mathrm{O}$ can go as low as $2 \mu \mathrm{M}$, 
whereas for CoHex it was $5 \mu \mathrm{M}$. Also, RuHex at concentrations below $20 \mu \mathrm{M}$ had a behavior similar to CoHex, where the signal takes a much longer time to reach the equilibrium.
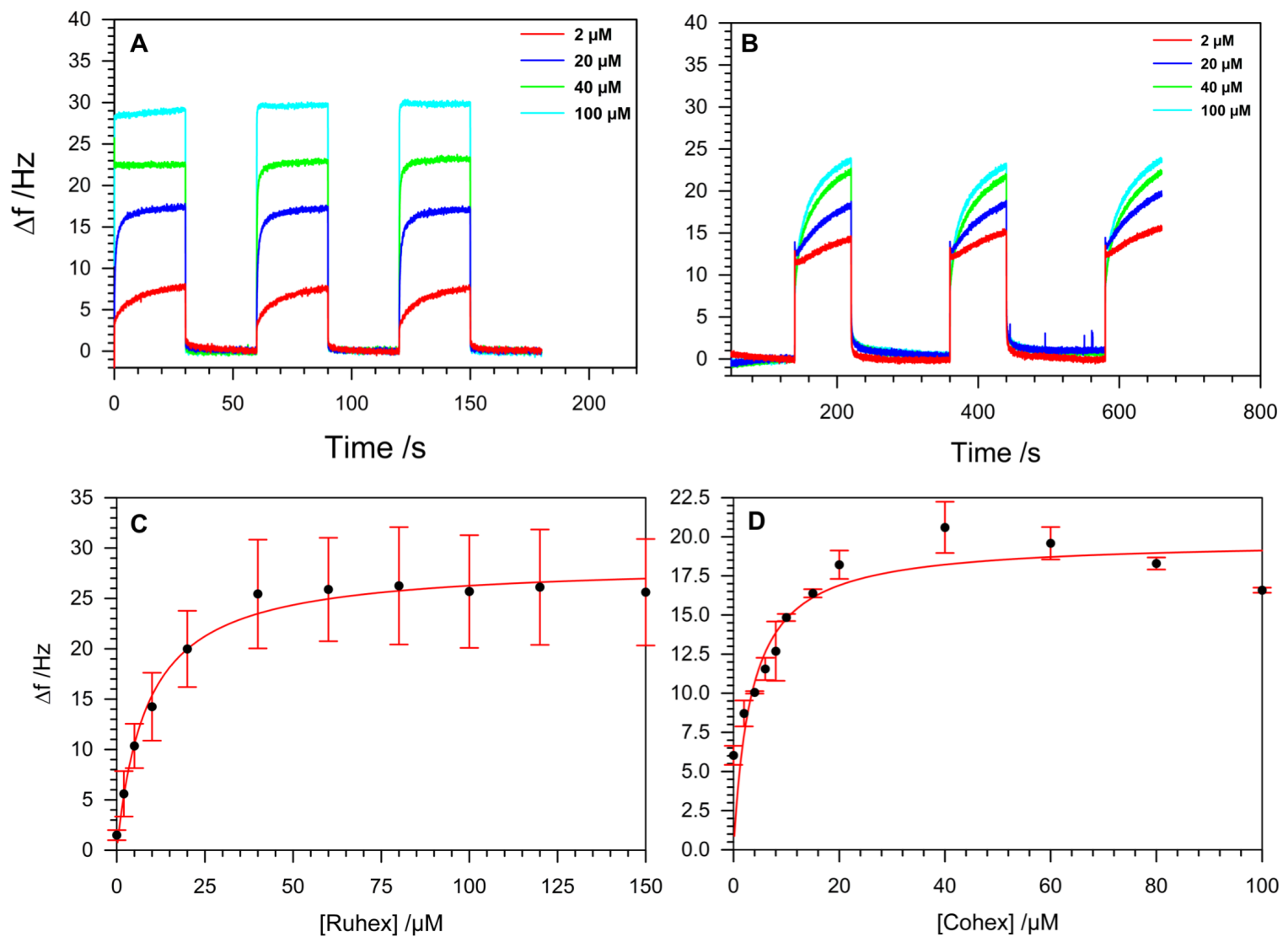

Figure 6. Effects of the metal complex concentration on the EQCM redox switching response of RuHex (A) and CoHex (B); the bottom panels depict the corresponding Langmuir isotherms for RuHex (C) and CoHex (D). Potential pulse lengths were $30 \mathrm{~s}$ for RuHex and $140 \mathrm{~s}$ for CoHex; $10 \mathrm{mM}$ Tris buffer made with $\mathrm{D}_{2} \mathrm{O}$ was adjusted to $\mathrm{pH} 7.5$ using $\mathrm{D}_{2} \mathrm{SO}_{4}$. Potential jump for RuHex was from $0.053 \mathrm{~V}$ to $-0.347 \mathrm{~V}$ and $0.2 \mathrm{~V}$ to $-0.6 \mathrm{~V}$ for CoHex.

The binding constants $\mathrm{K}_{d}$, for both RuHex and CoHex were calculated (Table 2) from the isotherm plots (Fig 6 C\&D) using a Langmuir-isotherm-type model ${ }^{[47]}$. Average $K_{d}$ and standard error values of three trials, each one with a new SAM are listed in Table 2. Binding constant of CoHex was higher than that of RuHex by a factor of $\sim 3$, indicating stronger binding with ssDNA. Compared to the $\mathrm{K}_{d}$ values in $\mathrm{H}_{2} \mathrm{O}$ based buffer, $\mathrm{K}_{d}$ values of CoHex in $\mathrm{D}_{2} \mathrm{O}$ based buffer were decreased very significantly (by a factor of $\sim 3$ ), whereas RuHex again did not show an isotope effect. These $K_{d}$ values further confirm the difference in the interactions with the ssDNA/MCH mixed SAM and the two redox complexes. 
Table 2: Binding constants of RuHex and CoHex to ssDNA/MCH mixed SAMs immobilized on a gold electrode surface

\begin{tabular}{|l|l|l|}
\hline Complex & $\mathbf{K}_{\mathbf{d}(\mathbf{D 2 0})} / \mathbf{M}^{-1 * 10^{6}}$ & $\mathbf{K}_{\mathbf{d}(\mathbf{H 2 O})} / \mathbf{M}^{-1 * 10^{6}}$ \\
\hline RuHex & $(0.117 \pm 0.013)$ & $(0.118 \pm 0.010)^{\mathrm{a}}$ \\
\hline CoHex & $(0.295 \pm 0.041)$ & $(1.04 \pm 0.211)^{\mathrm{a}}$ \\
\hline
\end{tabular}

${ }^{a} K_{d(H 2 O)}$ values were taken from our earlier paper ${ }^{[47]}$.

\subsection{Effect of Potential Pulse Amplitude on the Frequency Response}

Figure 7 illustrates the strong influence of the potential amplitude on the frequency response of $50 \mu \mathrm{M}$ CoHex in $10 \mathrm{mM}$ Tris buffer made with $\mathrm{H}_{2} \mathrm{O}$ and $\mathrm{D}_{2} \mathrm{O}$. The maximum frequency response was observed at an amplitude of $\sim( \pm 400 \mathrm{mV})$ for CoHex and $\pm 120 \mathrm{mV}$ for RuHex as reported in our earlier work ${ }^{[47]}$.

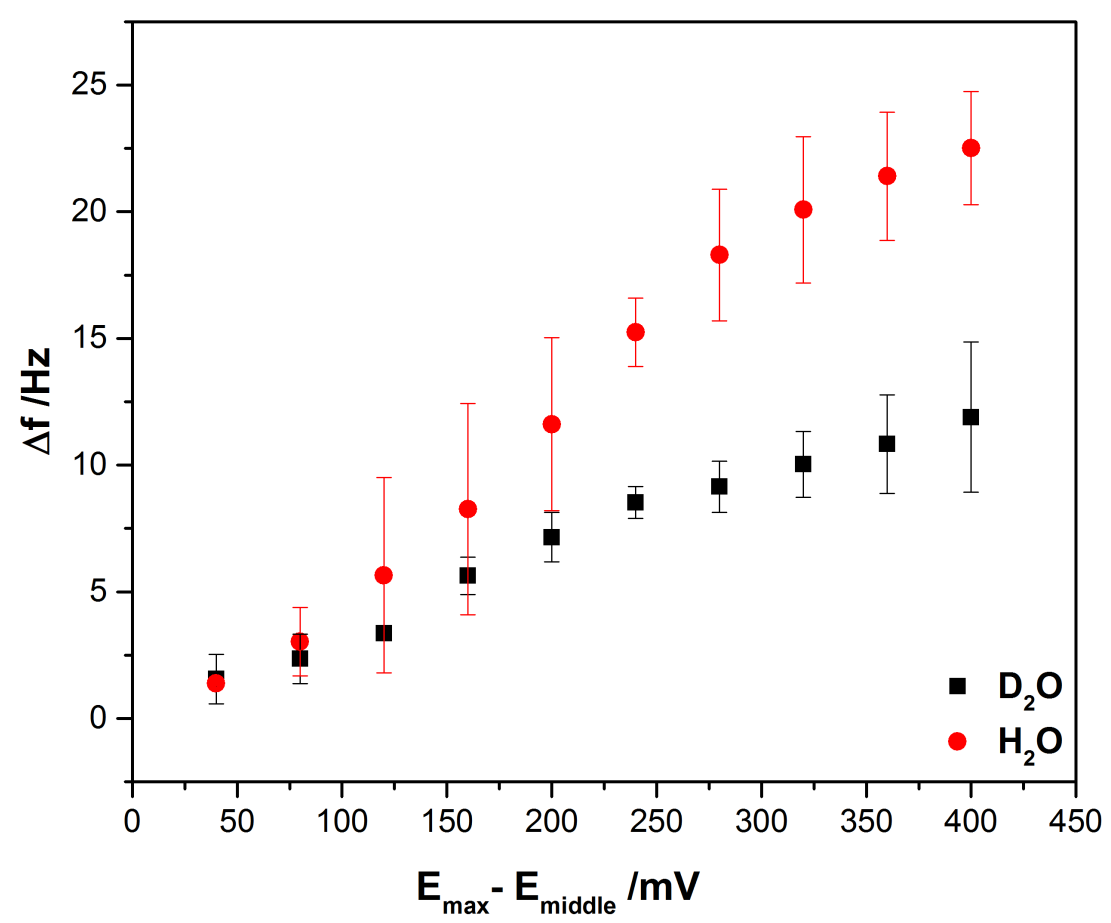

Figure 7. Effect of potential pulse amplitude on frequency shift values with $50 \mu \mathrm{M}$ CoHex in $10 \mathrm{mM}$ Tris/ $\mathrm{H}_{2} \mathrm{SO}_{4}$, pH 7.5 buffer made with $\mathrm{H}_{2} \mathrm{O}$ (red) and $\mathrm{D}_{2} \mathrm{O}$ (black).

Again, CoHex showed a different behavior with $\mathrm{H}_{2} \mathrm{O}$ and $\mathrm{D}_{2} \mathrm{O}$ based Tris buffer. For lower potential amplitude values (until $\pm 100 \mathrm{mV}$ ) the frequency response was quite similar in both $\mathrm{H}_{2} \mathrm{O}$ and $\mathrm{D}_{2} \mathrm{O}$ buffers, but as the potential amplitude increased, CoHex showed a larger increase in the frequency response in $\mathrm{H}_{2} \mathrm{O}$ based buffer than in $\mathrm{D}_{2} \mathrm{O}$ 
based buffer. Also, in the $\mathrm{D}_{2} \mathrm{O}$ based buffer the maximum frequency response was nearly reached at a potential amplitude of $\pm 250 \mathrm{mV}$ followed by a very small further increase in frequency response; whereas in $\mathrm{H}_{2} \mathrm{O}$ based buffer the response increased gradually till a potential amplitude of $\pm 400 \mathrm{mV}$ was applied. This difference in frequency response to the potential pulse amplitude further accounts for the isotope effect seen only with CoHex.

\section{Conclusion}

The first important observation we made was the difference in the redox behavior of RuHex and CoHex upon switching the electrolyte media from $\mathrm{H}_{2} \mathrm{O}$ to $\mathrm{D}_{2} \mathrm{O}$, where a consistent potential shift of $400 \mathrm{mV}$ (with EQCM Au electrode) and $250 \mathrm{mV}$ (Basi Au disk electrode) was seen for the reduction potential of CoHex, while no significant change was observed for RuHex in both CV and DPV studies. The potential shift was observed only in the presence of mixed SAMs of ssDNA \& $\mathrm{MCH}$ on the gold electrode surface. The second observation was the reduction in the EQCM frequency response (by $\sim 10 \mathrm{~Hz}$ ) in the presence of both RuHex and CoHex upon switching the potential from negative to positive and vice versa.

We concluded that the observed effects were caused by a combination of processes. One reason is the difference in the interaction of RuHex and CoHex with ssDNA. RuHex specifically interacts with the oxygen atoms of the negatively charged phosphate groups in the back bone of SSDNA, while CoHex could interact with oxygen atoms of the phosphate back bone, as well as with the nitrogen atoms of guanine bases, which could also lead to a conformational transition from the B-form of DNA to Z-form. Studies performed by Steichen et al. and Gautham et al. provide sufficient evidence for this claim. The next reason for these differences in isotope effects could be an outer shell rearrangement with the $\left[\mathrm{Co}\left(\mathrm{NH}_{3}\right)\right]^{3+/ 2+}$ redox couple upon the potential switch. These self-exchange reactions are affected by the orbitals involved in electron transfer. In case of $\left[\mathrm{Co}\left(\mathrm{NH}_{3}\right)\right]^{3+/ 2+}$ the reorganization energy is greater as electrons are moving to $\boldsymbol{\sigma}^{*}$ orbitals upon rearrangement, which in return makes the reaction even slower. Whereas for the $\left[\mathrm{Ru}\left(\mathrm{NH}_{3}\right)\right]^{3+/ 2+}$ redox couple the inner sphere reorganization is less extensive as the electron is being transferred between weakly antibonding or nonbonding $\pi$ orbitals, thus the reactions become much faster [57]. In summary, charge transfer for CoHex happens due to diffusion of 
this complex through the DNA-SAM, whereas RuHex enables electron hopping without any need for the RuHex to move through the SAM. This also explains the missing oxidation peak for CoHex, and it may be one of the reasons for the slow frequency response of CoHex during positive potential steps. The observed amplified $\mathrm{H} / \mathrm{D}$ isotope effects may be used as tools that allow to improve our understanding of isotope effects in medicinal and biomolecular settings that have been reported recently. The mechanisms are still widely unclear. The recently described chiral water superstructures interacting with DNA ${ }^{[56]}$ may be an interesting field to test our approach. Voltammetric and EQCM studies of H/D isotope effects can probably help to investigate amplified isotope effects not only with DNA, but also with larger protein molecules, as well as with potential organic drug molecules.

\section{Acknowledgements}

The authors are grateful to SUNY Albany for start-up funds. 


\section{References}

${ }^{1}$ Heyrovsky, J. \& Müller, O. H. Polarographic Studies with the Dropping Mercury Kathode. Part XLVIII. - Overpotential in Heavy water. Coll. Czech. Chem. Commun. 7, 281-287 (1935).

2 Conway, B. E. Kinetics of electrolytic hydrogen and deuterium evolution. Proc. Royal Soc. A 256, 128-144 (1960).

${ }^{3}$ Wang, Y., Zhu, G. \& Wang, E. Electrochemical quartz crystal microbalance study for vanadium hexacyanoferrates: monitoring of film growth and ion effects during redox reactions. J. Electroanal. Chem. 430, 127-132 (1997).

${ }^{4}$ Lasky, S. J. \& Buttry, D. A. Mass Measurements using Isotopically Labelled Solvents Reveal the Extent of Solvent Transport during Redox in Thin Film on Electrodes. J. Am. Chem. Soc. 110, 6258-6260 (1988).

5 Tse, E. C. M., Varnell, J. A., Hoang, T. T. H. \& Gewirth, A. A. Elucidating Proton Involvement in the Rate-Determining Step for Pt/Pd-Based and Non-Precious-Metal Oxygen Reduction Reaction Catalysts Using the Kinetic Isotope Effect. J. Phys. Chem. Lett. 7, 3542-3547 (2016).

${ }^{6}$ Malko, D. \& Kucernak, A. Kinetic isotope effect in the oxygen reduction reaction (ORR) over Fe-N/C catalysts under acidic and alkaline conditions. Electrochem. Commun. 83, 67-71 (2017).

${ }^{7}$ Chadderdon, X. H., Chadderdon, D. J., Matthiesen, J. E., Qiu, Y., Carraher, J. M., Tessonnier, J. -P. \& Li, W. Mechanisms of Furfural Reduction on Metal Electrodes: Distinguishing Pathways for Selective Hydrogenation of Bioderived Oxygenates. J. Am. Chem. Soc. 139, 14120-14128 (2017).

${ }^{8}$ Paul F. Fitzpatrick, Combining Solvent Isotope Effects with Substrate Isotope effects in Mechanistic studies of Alcohol and Amine Oxidation by Enzymes.

Biochimica et Biophysica Acta 1854, 1746-1755 (2015).

${ }^{9}$ Battistuzzi, G., Borsari, M., Ranieri, A. \& Sola, M. Solvent-based deuterium isotope effects on the redox thermodynamics of cytochrome c. J. Biol Inorg Chem. 9, 781787 (2004).

${ }^{10}$ Shirota, H., Tamoto, Y. \& Segawa, H. Dynamic Fluorescence Probing of the Microenvironment of Sodium Dodecyl Sulfate Micelle Solutions: Surfactant Concentration Dependence and Solvent Isotope Effect. J. Phys. Chem. A 108, 32443252 (2004).

${ }^{11}$ Maloney, A., Herskowitz, L. J. \& Koch, S. J. Effect of ${ }^{2} \mathrm{H}$ and ${ }^{18} \mathrm{O}$ water isotopes in kinesin-1 gliding assay, PeerJ 2 (2014) e284.

12 Kushner, D. J., Baker, A., Dunstall, T. G., "Pharmacological uses and perspectives of heavy water and deuterated compounds" Can. J. Physiol. Pharmacol. 77, 79-88, (1999). 
${ }^{13}$ Bachner, P., McKay, D. G., Rittenberg, D. "The pathologic anatomy of deuterium intoxication", Proc. Natl. Acad. Sci. USA, 51, 464-471 (1964).

14 L. S. Hohlefelder, T. Stögbauer, M. Opitz, T. M. Bayerl, J. O. Rädler, Heavy Water Reduces GFP Expression in Prokaryotic Cell-Free Assays at the Translation Level While Stimulating Its Transcription, BioMed Research International 2013, Article ID 592745, 9 pages.

15 F. Vergara, M. Itouga, R. Gamboa Becerra, M. Hirai, J.J. Ordaz-Ortiz, R. Winkler, Funaria hygrometrica Hedw. elevated tolerance to $\mathrm{D}_{2} \mathrm{O}$ : its use for the production of highly deuterated metabolites, Planta 247, 405 - 412 (2018).

16 J. Hartmann, Y. Bader, Z. Horvath, P. Saiko, M. Grusch, C. Illmer, S. Madlener, M. Fritzer-Szekeres, N. Heller, R.-G. Alken, T. Szekeres, Effects of Heavy Water $\left(\mathrm{D}_{2} \mathrm{O}\right)$ on Human Pancreatic Tumor Cells, Anticancer Research 25, 3407-3412 (2005).

${ }^{17}$ Strekalova, T., Evans, M., Chernopiatko, A., Couch, Y., Costa-Nunes, J., Cespuglio, R., Chesson, L., Vignisse, J., Steinbusch, H. W., Anthony, D. C., Pomytkin, I., Lesch, K.-P. Deuterium content of water increases depression susceptibility: The potential role of a serotonin-related mechanism, Behav. Brain Res. 277, 237-244 (2015).

${ }^{18}$ Somlyai, G., Jancso, G., Jakli, G., Vass, K., Barna, B., Lakics, V., Gaal, T. Naturally occurring deuterium is essential for the normal growth rate of cells, FEBS 317, 1-4 (1993).

${ }^{19}$ Boros, L. G., D’Agostino, D. P., Katz, H. E., Roth, J. P., Meuillet, E. J., Somlyai, G. Submolecular regulation of cell transformation by deuterium depleting water exchange reactions in the tricarboxylic acid substrate cycle, Medical Hypotheses 87, 69-74 (2016).

${ }^{20}$ Somlyai, G., Laskay, G., Berkenyi, T., Galbacs, Z., Galbacs, G., Kiss, S. A., Jakli, Gy., Jancso, G. The Biological effects of Deuterium-Depleted Water, a Possible New Tool in Cancer Therapy, J Oncol. 30, 91-94 (1988).

${ }^{21}$ Tanase, C., Boz, I., Stingu, A., Volf, I., Popa, V. I. Physiological and biochemical responses induced by spruce barkaqueous extract and deuterium depleted water with synergisticaction in sunflower (Helianthus annuus L.) plants, Ind. Crops Prod. 60, 160-167 (2014).

${ }^{22}$ Syroeshkin, A., Pleteneva, T., Uspenskaya, E., Zlatskiy, I., Antipova, N., Grebennikova, T., Levitskaya, O. D/H control of chemical kinetics in water solutions under low deuterium Concentrations, Chem. Eng. J. (2018) in press, https://doi.org/10.1016/j.cej.2018.08.213.

23 Ong, W. Q., Citron, Y. R., Schnitzbauer, J., Kamiyama, D., Huang, B. Heavy water: a simple solution to increasing the brightness of fluorescent proteins in superresolution imaging, Chem. Commun. 51 (2015) 13451-13453. 
${ }^{24}$ Atzrodt, J., Derdau, V., Kerr, W. J., Reid, M. Deuterium- and Tritium-Labelled Compounds: Applications in the Life Sciences, Angew. Chem. Int. Ed. 57, 1758-1784 (2018).

25 Das, J., Lee, J.-A. \& Yang, H. Ultrasensitive Detection of DNA in Diluted Serum Using $\mathrm{NaBH}_{4}$ Electrooxidation Mediated by $\left[\mathrm{Ru}\left(\mathrm{NH}_{3}\right)_{6}\right]^{3+}$ at Indium-Tin Oxide Electrodes. Langmuir. 26, 6804-6808 (2010).

${ }^{26}$ Wu, V. C. H., Chen, S.-H. \& Lin, C.-S. Real-time detection of Escherichia coli O157:H7 sequences using a circulating-flow system of quartz crystal microbalance. Biosens. Bioelectron. 22, 2967-2975 (2007).

${ }^{27}$ Kleo, K., Kapp, A., Ascher, L. \& Lisdat, F. Detection of vaccinia virus DNA by quartz crystal microbalance. Anal. Biochem. 418, 260-266 (2011).

${ }^{28}$ Quan, X., Heiskanen, A., Tenje, M. \& Boisen, A. In-situ monitoring of potential enhanced DNA related processes using electrochemical quartz crystal microbalance with dissipation (EQCM-D). Electrochem. Commun. 48, 111-114 (2014).

${ }^{29}$ Fan, C., Plaxco, K. W., \& Heeger, A. J. Electrochemical interrogation of conformational changes as a reagentless method for the sequence-specific detection of DNA. PNAS. 100, 9134-9137 (2003).

30 Duwensee, H., Mix, M., Stubbe, M., Gimsa, J., Adler, M. \& Flechsig, G.-U. Electrochemical product detection of an asymmetric convective polymerase chain reaction. Biosens. Bioelectron. 25, 400-405 (2009).

${ }^{31}$ Wang, T., Zhou, L., Zhang, Z., Li, J., Jing, X. \& Xie, G. Ultraspecific electrochemical DNA biosensor by coupling spontaneous cascade DNA branch migration and dual-signaling sensing strategy. Biosens. Bioelectron. 78, 464-470 (2016).

${ }^{32}$ Fojta, M., Havran, L., Kizek, R., Billova, S. \& Palecek, E. Multiply osmium-labeled reporter probes for electrochemical DNA hybridization assays: detection of trinucleotide repeates. Biosens. Bioelectron. 20, 985-994 (2004).

${ }^{33}$ Peter, J., Reske, T. \& Flechsig, G.-U. Comparison of DNA Hybridization at Rotating and Heated Gold Disk Electrodes. Electroanalysis 19, 1356-1361 (2007).

34 Joda, H., Sedova, A., Awan, W. \& Flechsig, G.-U. The Osmium Tetroxide Bipyridine-labeled DNA Probe: Hairpin Conformations and Characterization of Redox-label Behavior. Electroanalysis 29, 51-59 (2017).

${ }^{35}$ Metrohm-Autolab, Autolab EQCM User Manual 7/2011, p. 39.

${ }^{36}$ Gessner, R. V., Quigley, G. J., Wang, A. H., van der Marel, G. A., van Boom, J. H., \& Rich, A., Structural basis for stabilization of Z-DNA by cobalt hexaammine and magnesium cations. Biochemistry. 24, 237-240 (1985). 
${ }^{37}$ Murphy, J. N., Cheng, A. K. H., Yu, H.-Z. \& Bizzotto, D. On the Nature of DNA SelfAssembled Monolayers on Au: Measuring Surface Heterogeneity with

Electrochemical in Situ Fluorescence Microscopy. J. Am. Chem. Soc. 131, 40424050 (2009).

${ }^{38}$ Doneux, T., De Rache, A., Triffaux, E., Meunier, A., Steichen, M. \& Buess-Herman, C. Optimization of the Probe Coverage in DNA Biosensors by a One-Step Coadsorption Procedure. ChemElectroChem 1, 147-157 (2014).

39 Steel, B., Herne, T.M. \& Tarlov, M.J. Electrochemical Quantitation of DNA Immobilized on Gold. Anal. Chem. 70, 4670-4677 (1998).

${ }^{40}$ Grubb, M., Wackerbarth, H. \& Ulstrup, J. Identification of Single-Strand DNA by in situ Scanning Tunneling Microscopy, J. Am. Chem. Soc. 128, 7734-7735 (2006).

${ }^{41}$ Sosnowski, R. G., Tu, E., Butler, W. F., O’Connell, J. P. \& Heller, M. J. Rapid determination of single base mismatch mutations in DNA hybrids by direct electric field control. PNAS 94, 1119-1123 (1997).

${ }^{42}$ Hassmann, J., Misch, A., Schülein, J., Krause, J., GraßI, B., Müller, P. \& Bertling, W. M. Development of a molecular diagnosis assay based on electrohybridization at plastic electrodes and subsequent PCR. Biosens. Bioelectron. 16, 857-863 (2001).

43 Jambrec, D., Gebala, M., La Mantia, F. \& Schuhmann, W. Potential-Assisted DNA Immobilization as a Prerequisite for Fast and Controlled Formation of DNA Monolayers. Angew. Chem. Int. Ed. 54, 15064-15068 (2015).

44 Mahajan, S., Richardson, J., Brown, T. \& Bartlett, P. N. SERS-Melting: A New Method for Discriminating Mutations in DNA Sequences. J. Am. Chem. Soc. 130, 15589-15601 (2008).

45 Tsortos, A., Papadakis, G. \& Gizeli, E. Shear acoustic wave biosensor for detecting DNA intrinsic viscosity and conformation: A study with QCM-D. Biosens. Bioelectron. 24, 836-841 (2008).

${ }^{46}$ Sun, L., Frykholm, K., Fornander, L. H., Svedhem, S., Westerlund, F. \& Akerman, B. Sensing Conformational Changes in DNA upon Ligand Binding Using QCM-D.

Polyamine Condensation and Rad51 extension of DNA layers. J. Phys. Chem. B 118, 11895-11904 (2014).

${ }^{47}$ Peter, J., Galagedera, S.K.K. \& Flechsig, G.-U., Redox-Induced Switching of the Viscoelasticity of DNA Layers Observed by EQCM on the Millisecond Timescale, ChemElectroChem 5, 418-424 (2018).

48 Thiyagarajan, S., Rajan, S. S. \& Gautham, N., Cobalt hexammine induced tautomeric shift in Z-DNA: the structure of d(CGCGCA).d(TGCGCG) in two crystal forms. Nucleic Acids Research 32, 5945-5953 (2004). 
49 Hubbard, A. T. Study of the kinetics of electrochemical reactions by thin-layer voltammetry, J. Electroanal. Chem. 22 , 165-174 (1969).

${ }^{50}$ Krumbiegel, P. Large deuterium isotope effects and their use: a historical review, Isot. Environ. Health Stud. 47, 1-17 (2011).

51 Soleymani, L., Fang, Z., Sargent, E. H. \& Kelley, S. O., Programming the detection limits of biosensors through controlled nanostructuring. Nat Nanotechnol 4, 844-848 (2009).

${ }^{52}$ Bard, A. J. \& Faulkner, L. R., Electrochemical Methods, Fundamentals and Applications, $2^{\text {nd }}$ Ed., John Wiley, New York 2001, p. 274.

${ }^{53}$ Celeste, M., Azevedo, C. \& Cavaleiro, A. M. V. The Acid-Base Titration of a Very Weak Acid: Boric Acid, J. Chem. Educ. 89 ,767-770 (2012).

${ }^{54}$ Schulze, G. \& Simon, J. Jander/Jahr Maßanalyse, 16 ${ }^{\text {th }}$ Ed., Walter de Gruyter, Berlin 2003, pp. 209-211.

${ }^{55}$ Grubb, M., Wackerbarth, H., Wengel, J. \& Ulstrup, J. Direct Imaging of HexaamineRuthenium(III) in Domain Boundaries in Monolayers of Single-Stranded DNA, Langmuir 23, 1410-1413 (2007).

${ }^{56}$ McDermott, M. L., Vanselous, H., Corcelli, S. A. \& Petersen, P. B. DNA's Chiral Spine of Hydration, ACS Cent. Sci. 3, 708-714 (2017).

${ }^{57}$ Atkins, P., Overton, T., Rourke, J., Weller, M. \& Armstrong, F., 2010, Shriver \& Atkin's Inorganic Chemistry, New York, W. H. Freeman and Company, 527-528. 